\title{
Perancangan Sistem Kendali Kendaraan Bermotor Jarak Jauh Menggunakan NodeMCU ESP8266
}

\author{
Choresy Michael G. Butar-Butar ${ }^{1}$, Yusran Timur Samuel ${ }^{2}$ \\ 1,2 Fakultas Teknologi Informasi Universitas Advent Indonesia \\ e-email: ${ }^{1}$ choressy911@gmail.com, ${ }^{2}$ y.tarihoran@unai.edu
}

\begin{abstract}
Abstrak
Menghidupkan kendaraan bermotor dari jarak jauh adalah merupakan satu kendala bagi pemilik kendaraan bermotor, hal ini dapat terjadi apabila dia bepergian jauh dan tidak ada orang yang dapat menghidupkan kendaraannya. Untuk itu penulis membuat suatu penelitian untuk memanfaatkan teknologi IoT (internet of things) yang dapat mematikan dan menghidupkan kendaraan bermotor dari jarak jauh. Dengan menggunakan NodeMCU ESP8266 yang dihubungkan dengan 2 relay dan 2 sensor yaitu sensor getar SW420 dan sensor kemiringan (tilt) SW460D dapat menghasilkan konfigurasi hardware untuk mengendalikan kendaraan bermotor jarak jauh. Sebagai antar muka pengendali, telah dibuat satu aplikasi yang diprogram menggunakan aplikasi Blynk yang berbasis android. Rancangan yang penulis teliti ini, telah di uji cobakan kepada sepeda bermotor dari tanggal 1 Maret hingga 1 April, di mana hasilnya selalu berhasil mengendalikan kendaraan bermotor dari jarak jauh jika sistem ini mendapatkan sinyal wifi dengan koneksi internet.
\end{abstract}

Kata-kata Kunci: IoT, NodeMCU ESP8266, Sensor getar SW420, sensor kemiringan SW460D.

\section{A Design of Distance Control System for Vehicle Using NodeMCU ESP8266}

\begin{abstract}
Turning on a vehicle from a distance is an obstacle for the owners. This happens if he travels far and no one can turn on the vehicle. For this reason, the authors conduct a study to utilize IoT technology (internet of things) that can turn off and turn on a vehicle remotely. By using ESP8266 NodeMCU which is connected with 2 relays and 2 sensor that is a SW420 vibration sensor and a tilt sensor the SW460D can produce a hardware configuration to control the vehicles from a distance. As an interface controller, one application has been programmed using the Android-based Blynk application. This design has been tested on a motorcycle for a month, from March 1 to April 1. the result shows that it works, and it is always succeeded to control the motorcycle from a far if the system gets a wifi signal with an internet connection.
\end{abstract}

Keywords: IoT, NodeMCU, SW420 vibration sensor, SW460D tilt sensor.

\section{Pendahuluan}

Pemanfaatan teknologi internet sudah berkembang dengan sangat pesat, ini didorong oleh tersedianya perangkat keras internet dengan harga relatif murah dan tersedianya berbagai perangkat lunak yang dapat diprogram atau dikonfigurasi dengan cara yang relatif mudah. Berdasarkan fenomena tersebut maka dewasa ini berkembang konsep IoT (Internet of Things) yaitu memanfaatkan teknologi internet untuk mengendalikan peralatan-peralatan elektronik yang terdapat dalam kehidupan sehari-hari seperti mematikan dan menghidupkan lampu, mengendalikan kulkas, Tv dan lain-lain menggunakan perangkat komputer atau smartphone. Dengan adanya fenomena tersebut, maka berbagai peralatan dapat 
dikendalikan dengan hanya menggunakan sebuah smartphone dan pengendalian tersebut dapat dilakukan dari jarak jauh.

Untuk lebih memperluas pemanfaatan internet dalam kehidupan sehari-hari maka penulis tertarik untuk mengadakan penelitian tentang pemanfaatan internet untuk pengendalian kendaraan bermotor jarak jauh. Hal ini ditujukan kepada mereka yang memiliki kendaraan bermotor, namun sering bepergian jarak jauh meninggalkan kendaraannya beberapa hari atau bahkan beberapa minggu. Sebagaimana kita ketahui bahwa kendaraan bermotor membutuhkan pemeliharaan. Salah satu hal yang perlu diperhatikan oleh pemilik kendaraan adalah, tidak baik jika kendaraan bermotor tidak dihidupkan dalam jangka waktu yang lama. Beberapa efek kendaraan bermotor yang tidak dihidupkan dalam jangka lama seperti, habis baterai [1], pelumas yang mengendap di dasar mesin dan efek lain yang tidak baik bagi kendaraan bermotor tersebut. Untuk itu diperlukan suatu sistem yang dapat mengendalikan kendaraan bermotor dari jarak jauh.

Sudah ada beberapa penelitian yang membahas tentang bagaimana menghidupkan kendaraan bermotor dari jarak jauh khususnya sepeda motor[2] yang menggunakan telepon selular dengan sistem pengenalan sinyal DTMF. Kemudian penelitian tentang bagaimana menyalakan (start engine) dan menyalakan alarm pada sepeda motor menggunakan arduino uno berbasis android [3]. Penelitian ini menggunakan b/uetooth $\mathrm{HC}-05$ untuk menerima perintah yang dikirim dari perangkat android. Namun sejauh yang peneliti ketahui belum ada penelitian yang menggunakan WiFidan memiliki umpan balik untuk menentukan apakah motor sudah hidup atau belum dan menentukan apakah posisi motor miring atau tegak menggunakan kaki dua, sebab untuk motor khususnya jenis matic, tidak dapat dihidupkan apabila standar (kaki) samping tidak ditarik atau dilipat.

Oleh karena itu penulis tertarik untuk mengadakan penelitian tentang bagaimana merancang suatu sistem untuk menghidupkan kendaraan bermotor dari jarak jauh dengan memanfaatkan teknologi IoT menggunakan WiFi berbasis android. Kemudian penulis juga meneliti tentang bagaimana menggunakan sensor getar untuk menentukan apakah motor sudah menyala atau belum dan mengetahui apakah kondisi motor berada pada posisi yang siap untuk di starter dengan sensor kemiringan, sebab motor yang menggunakan kaki samping, akan mengakibatkan posisi motor yang miring sehingga tidak bisa di hidupkan. Dengan demikian diharapkan kendaraan bermotor yang ditinggal dengan jarak yang jauh dapat tetap dihidupkan sehingga meminimalisasi efek negatif dari kendaraan bermotor yang tidak dihidupkan dengan waktu yang cukup lama.

Dalam penelitian ini, kendaraan bermotor yang dimaksud hanya meneliti sepeda motor roda dua saja, di mana secara umum, cara untuk menghidupkan sepeda motor, mobil, dan kendaraan bermesin lainnya, menggunakan prinsip yang sama. Sedangkan pengendalian, dibatasi hanya pada menyalakan dan mematikan mesin motor.

\section{Landasan Teori}

\section{Definisi Internet of Things}

Internet of Things (IoT) adalah sebuah teknologi yang mampu menyelesaikan permasalahan seharihari dengan memanfaatkan interkoneksi baik secara fisik maupun virtual menggunakan layanan internet. Internet of Things terdiri dari dua buah kata yaitu Internet dan Things. Internet adalah jaringan komputer yang digunakan untuk berkomunikasi dan berbagi informasi di ruang lingkup tertentu menggunakan protokol internet (TCP/IP), sementara things dapat diartikan sebagai peralatan-peralatan yang dapat dihubungkan dengan sensor dan tersambung dengan internet untuk mengirimkan keadaan peralatan tersebut. Namun informasi yang didapatkan melalui sensor tersebut perlu diolah agar dapat dimengerti oleh pemakai, untuk itu diperlukan teknologi semantic. [4]

Dengan demikian komponen Internet of Thing terdiri dari 3 komponen yaitu Internet, Things dan Semantic. Gambar 1. berikut ini menggambarkan konsep utama, teknologi dan standarisasi dari paradigma Internet of Things [5]. 


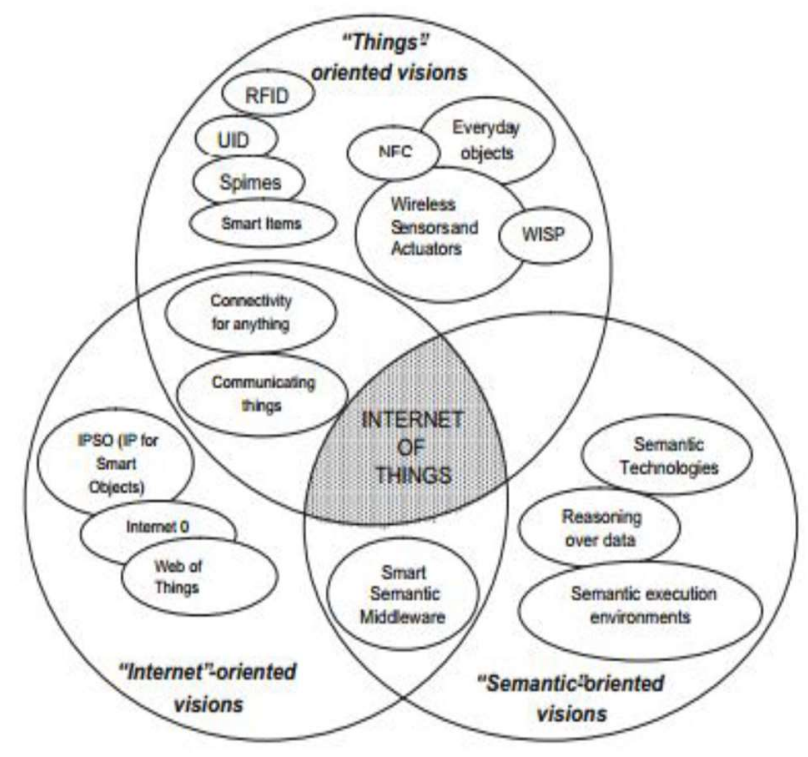

Gambar 1 Komponen Pendukung Internet of Things [4]

\section{Model Referensi IoT}

Menurut Sitrusta [4], Model referensi IoT (Gambar 2) terdiri dari 4 layer dan 2 kemampuan pendukung. 4 layer tersebut adalah :

1. Layer Aplikasi : Pada layer inilah seluruh aplikasi dari IoT berada.

2. Layer Layanan dan Pendukung Aplikasi. Pada layer ini terdapat 2 kelompok yaitu :

- Layanan Dukungan Generic seperti pengolahan data atau penyimpanan data.

Kemampuan ini dapat juga dipanggil oleh kemampuan dukungan khusus.

- Kemampuan Dukungan Khusus : Kemampuan untuk memberi fungsi pendukung yang berbeda beda untuk aplikasi IOT.

3. Layer Jaringan. Terbagi menjadi dua bagian yaitu :

- Kemampuan Membangun Jaringan yaitu kemampuan untuk menyediakan fungsi kontrol terhadap konektivitas jaringan.

- Kemampuan Transportasi : Menyediakan konektivitas untuk pengangkutan layanan IOT dan aplikasi informasi data khusus, serta transportasi kontrol IOT.

4. Layer Perangkat. Dapat dibagi ke dalam dua kelompok :

- Kemampuan Perangkat : Kemampuan interaksi langsung dengan jaringan komunikasi secara langsung maupun tidak langsung. Kemampuan interaksi dengan jaringan $\mathrm{Ad}-\mathrm{Hoc}$.

- Kemampuan Gateway: Kemampuan untuk mendukung berbagai jenis teknologi kabel atau nirkabel, seperti Controller Area Network (CAN), ZigBee, Bluetooth atau WiFi. Pada layer jaringan, gateway memiliki kemampuan untuk dapat berkomunikasi dengan berbagai teknologi, seperti PSTN (Public Switched Telephone Network), generasi kedua atau generasi ketiga (2G atau 3G), jaringan LTE (Long-Term Evolution), Ethernet atau DSL (Digital Subscriber Lines). [4] 


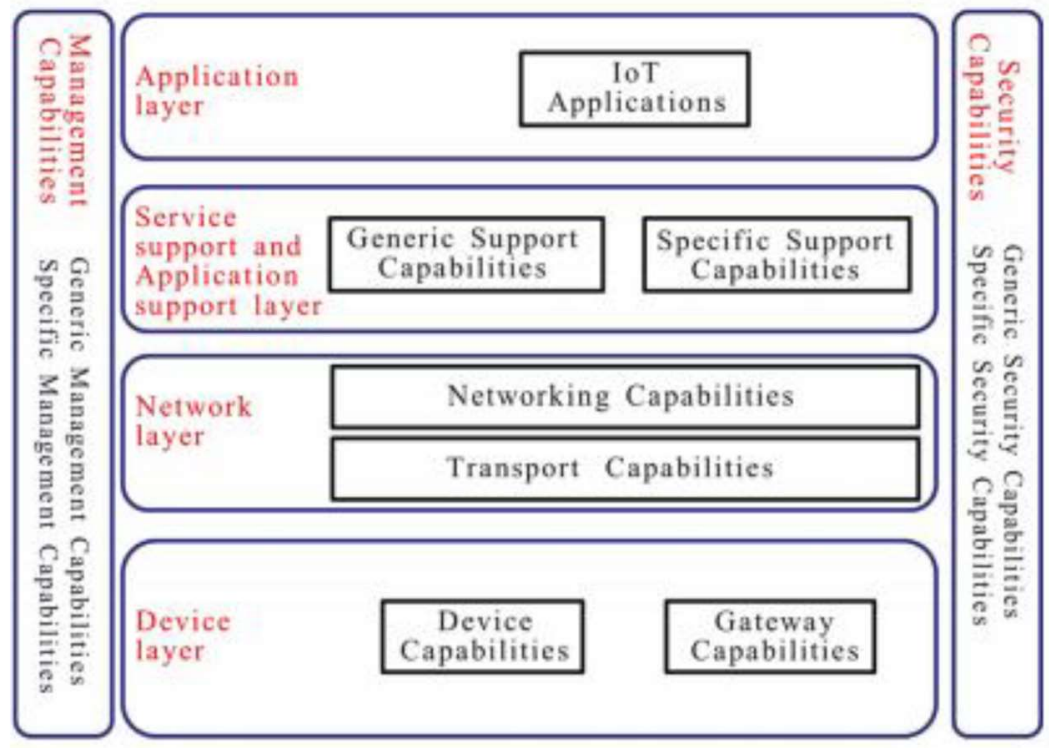

Gambar 2 Model Referensi Internet of Things [4]

\section{NodeMCU ESP8266 ESP12}

Pada penelitian ini, penulis menggunakan microcontroller yang sudah dilengkapi dengan modul WiFi dengan chipset ESP8266. Gambar 3 berikut ini adalah gambar NodeMCU ESP8266 ESP12.

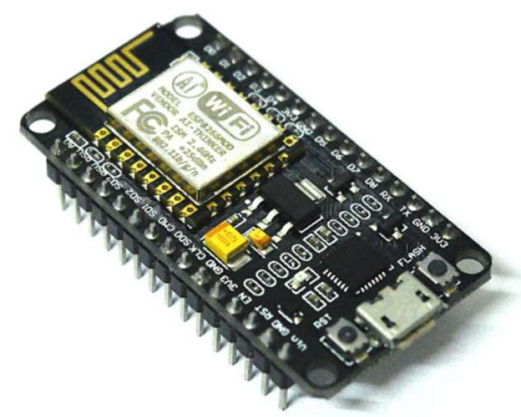

Gambar 3 NodeMCU ESP8266

NodeMCU adalah platform IoT yang open source, alat ini memiliki firmware yang jalan di atas ESP8266 WiFi SoC yang dibuat oleh Espressif Systems. Perangkat kerasnya berbasis modul ESP-12. NodeMCU ESP8266 menggunakan standar wireless IEEE $802.11 \mathrm{~b} / \mathrm{g} / \mathrm{n}$ dengan range frekuensi $2.412-2.484 \mathrm{GHz}$. Memiliki jenis security WEP/WPA-PSK/WPA2-PSK, dan jenis enkripsi WEP64/WEP128/TKIP/AES. Pin diagram dari NodeMCU ESP8266 dapat dilihat pada Gambar 4 berikut ini. 


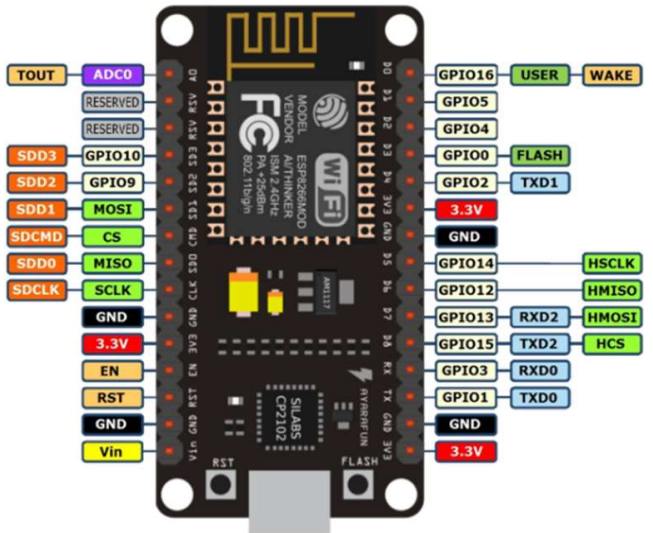

Gambar 4 Pin Diagram NodeMCU ESP8266 [6]

\section{Relay}

Relay adalah sakelar yang dioperasikan secara elektrik, kebanyakan relay menggunakan electromagnetic untuk mengadakan gerakan buka tutup atau on/off arus listrik. Biasanya relay ini menggunakan arus yang lemah (volt dan ampere kecil) untuk mematikan atau menghidupkan arus yang lebih tinggi baik volt dan ampere-nya. Pada gambar 5 berikut ini adalah relay yang digunakan untuk Arduino di mana arus pengendalinya $5 \mathrm{~V}$ dan dapat digunakan sebagai sakelar arus untuk kapasitas $\mathrm{AC}$ hingga 250V 10A, dan DC hingga 30V 10A.

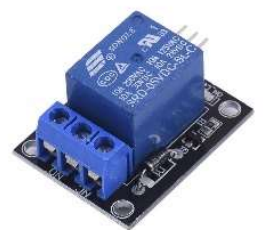

Gambar 5 Relay 1 Channe/ untuk Arduino

Relay biasanya digunakan sebagai sakelar untuk peralatan seperti: sistem kontrol lampu, peralatan telekomunikasi, pengontrol proses industri, kontrol lalu lintas, kontrol drive motor, sistem perlindungan tenaga listrik, komputer, peralatan otomotif serta peralatan rumah tangga.

\section{Sensor Getaran SW420 (Vibration Switch Sensor)}

Kegunaan sensor ini adalah untuk mendeteksi apakah ada getaran atau tidak, Bila tidak ada getaran, sensor getaran terhubung dan nilai output rendah. Lampu indikator menyala. Bila terdeteksi getaran, sensor segera terputus dan nilai output tinggi. Lampu indikator tidak menyala. Output-nya dapat langsung dihubungkan ke microcontroller untuk mendeteksi nilai rendah dan tinggi sehingga dapat diketahui apakah sedang terjadi getaran atau tidak.

Sensor getar biasanya digunakan pada alarm motor/mobil/jendela/pintu rumah. Tegangan kerja sensor ini adalah 3.3V-5V dengan menggunakan comparator LM393. Dalam penelitian ini, sensor digunakan untuk mendeteksi apakah motor sudah menyala atau tidak dengan mendeteksi getaran. Karena motor yang menyala pasti akan menghasilkan getaran. Gambar 6 berikut adalah sensor getar yang digunakan pada penelitian ini. 


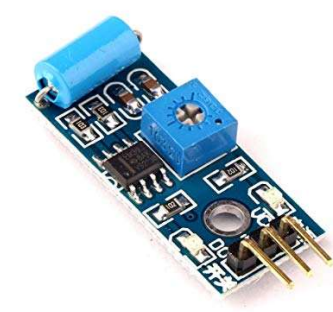

Gambar 6 Sensor Getar SW420

\section{Sensor Kemiringan SW460D}

Sensor ini sering juga disebut dengan tilt sensor, yaitu sensor yang dapat mendeteksi perubahan pada sudut kemiringan. Ketelitian hingga 15-45 derajat. Sensor ini sering digunakan untuk sistem monitoring tekanan ban, lampu sepeda, rotasi bingkai foto digital, rotasi layer kamera video, aplikasi antimaling, dll. Sensor ini menggunakan chip comparator LM393 yang stabil dan tingkat sensitifnya dapat diatur dengan potensiometer warna biru yang sudah tersedia. Sensor ini memiliki 3 kaki, yaitu VCC yang dapat dihubungkan dengan arus 3.3v s/d 5v, GND sebagai negatif dan DO untuk digital output.

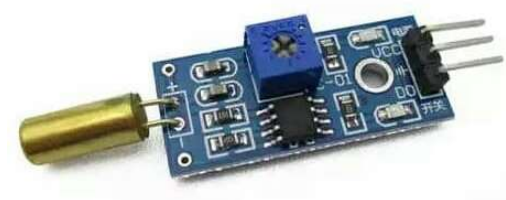

Gambar 7 Sensor Kemiringan SW460D

\section{Penelitian Sebelumnya}

Sudah ada penelitian tentang bagaimana mengendalikan motor dari jarak jauh yaitu menghidupkan dan mematikan sepeda motor menggunakan telepon seluler. Metode yang digunakan adalah dengan menggunakan microcontroller AT Mega 16. Untuk menghidupkan sepeda motor menggunakan tombol 1 dan mematikan menggunakan tombol 2 dari telepon selularnya. Untuk mengenali sinyal ini digunakan IC DTMF MT8870, yang selanjutnya diproses oleh microcontroller untuk menghidupkan atau mematikan mesin motor[2].

Pengendalian jarak jauh lainnya adalah untuk menghidupkan dan mematikan lampu listrik di rumah. Penelitiannya menggunakan Arduino dan Modul Wifi Esp8266. Interface dibuat berbasis web dengan HTML5. Arduino dihubungkan dengan relay dan menerima instruksi untuk menghidupkan dan mematikan lampu. [7].

Kemudian penelitian lain tentang menghidupkan mesin (start engine) dan menyalakan alarm pada sepeda motor menggunakan arduino uno berbasis android [3]. Penelitian ini menggunakan bluetooth HC05 untuk menerima perintah yang dikirim dari perangkat telepon berbasis android.

\section{Metode Penelitian}

\section{Analisa Kebutuhan Hardware dan Software}

Pada Penelitian ini, penulis menggunakan beberapa peralatan ( hardware) untuk dapat mengendalikan motor jarak jauh via internet di antaranya NodeMCU ESP8266, modul ini adalah microcontroller yang sudah 
memiliki kemampuan untuk terhubung dengan WiFi dan dapat diprogram untuk menerima dan mengeluarkan sinyal melalui kaki-kakinya. NodeMCU ESP8266 dihubungkan dengan relay sehingga dapat digunakan sebagai pemutus atau penyambung arus. Arus yang perlu di kendalikan adalah arus posisi kunci kontak on atau off dan arus tombol starter (menekan atau melepas starter), sehingga dalam perancangan sistem ini membutuhkan dua buah relay. Untuk mengetahui apakah motor sudah hidup atau belum, bisa dipantau dari getaran dari motor. Sehingga dibutuhkan sensor getar. Sensor getar yang digunakan adalah SW420. Dan sebagaimana lazimnya motor berjenis matic, jika standar samping digunakan untuk menyanggah, maka motor tidak dapat di starter. Untuk mengetahui apakah standar samping digunakan atau tidak, bisa dilihat dari kemiringan. Untuk mengetahui kondisi ini, digunakan sensor kemiringan SW460D.

Software yang digunakan pada penelitian ini adalah Arduino (IDE), merupakan aplikasi yang sudah terintegrasi untuk melakukan pengembangan pada microcontroller. Arduino menggunakan bahasa pemrograman sendiri yang menyerupai bahasa $\mathrm{C}$. Arduino IDE dibuat dengan menggunakan bahasa pemrograman JAVA. Arduino IDE juga dilengkapi dengan library $\mathrm{C} / \mathrm{C}++$ yang biasa disebut Wiring yang membuat operasi input dan output menjadi lebih mudah. Software lain yang digunakan adalah Blynk. Blynk adalah platform untuk aplikasi OS Mobile (iOS dan Android) yang bertujuan untuk kendali modul Arduino, Raspberry Pi, ESP8266, WEMOS D1, dan modul sejenisnya melalui Internet. Jadi pada program inilah diatur tampilan kendali motor jarak jauh yang dapat dijalankan melalui aplikasi berbasis android.

\section{Perancangan Sistem}

Arsitektur sistem pengendalian motor jarak jauh dapat dilihat pada Gambar 8 berikut ini.

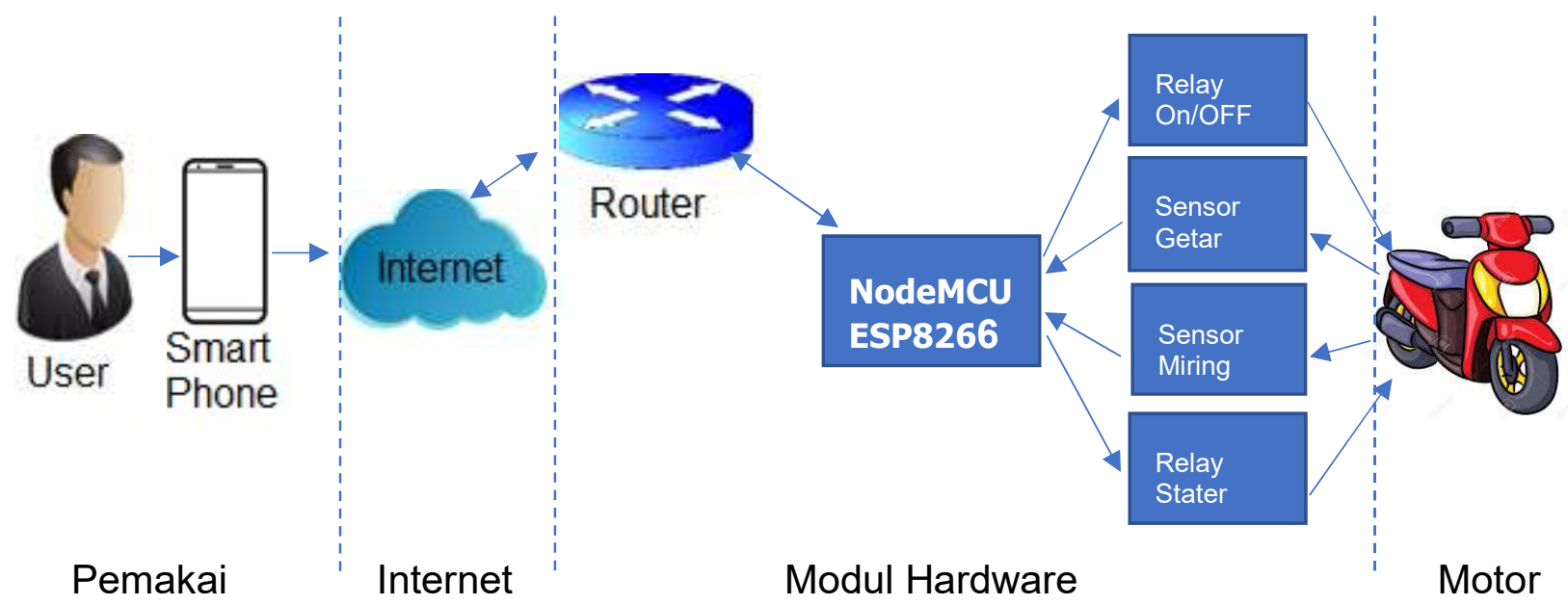

Gambar 8 Arsitektur Pengendalian Motor Jarak Jauh

Sistem ini terbagi dalam 4 bagian, yaitu: pemakai, internet, modul hardware dan motor yang dikendalikan. Pemakai adalah orang yang akan menghidupkan motornya dari jarak jauh menggunakan aplikasi berbasis android. Aplikasi yang dirancang berbasis android akan melakukan komunikasi ke perangkat microcontroller via internet. Microcontroller dapat mengaktifkan relay starter atau relay on/off sesuai kebutuhan setelah mendapatkan informasi dari sensor kemiringan dan sensor getar. Apabila sensor getar menerima sinyal positif yang berarti motor hidup atau bergetar maka proses starter tidak dapat dilakukan sampai kondisi motor mati. Sedangkan sensor kemiringan berfungsi untuk melihat apakah motor menggunakan standar kaki dua atau satu (standar samping). Jika motor sedang menggunakan standar samping maka fungsi starter tidak dapat dijalankan atau tombol starter tidak aktif. Gambar 9 berikut ini menunjukkan flowchart dari sistem yang dibangun. 


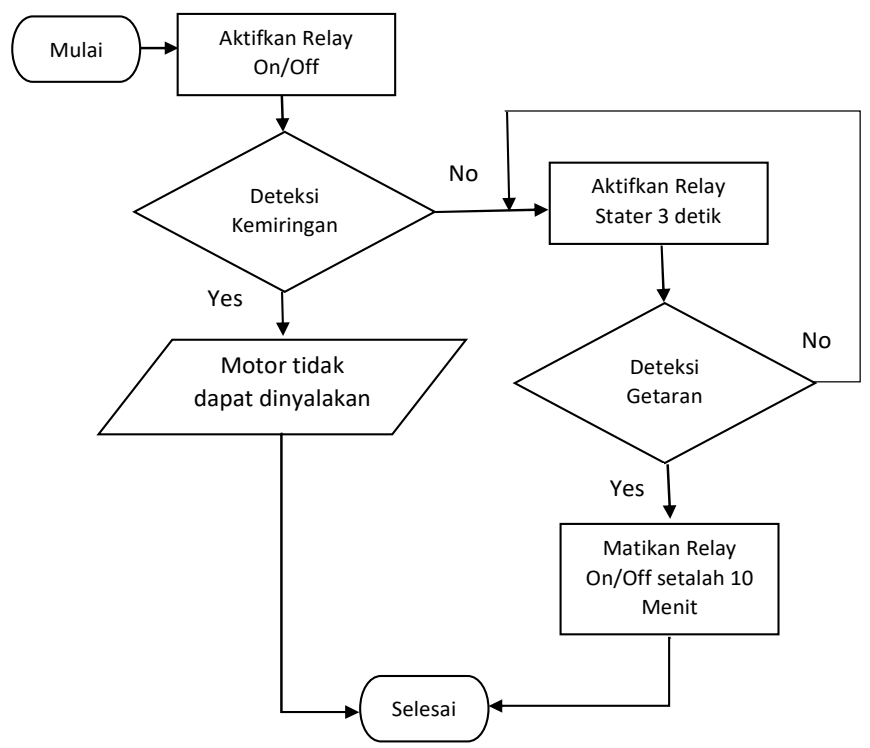

Gambar 9 Flowchart Sistem Pengendalian Motor Jarak Jauh

Dari Gambar 9 terlihat bahwa motor tidak dapat dinyalakan apabila sensor kemiringan mendeteksi motor miring, atau tidak menggunakan standar kaki dua. Hal tersebut sesuai dengan ketentuan pabrik bahwa motor tidak dapat dihidupkan jika menggunakan standar samping. Bila sensor kemiringan mendeteksi motor menggunakan standar kaki dua, maka motor di starter selama 3 detik dan apabila sudah hidup yang ditandai dengan sensor getar memberi nilai $H I G H$, maka motor akan menyala selama 10 menit dan akan membuat relay on/off berada pada posisi off.

\section{Hasil dan Implementasi}

Konfigurasi hardware untuk pengendali motor jarak jauh dengan memanfaatkan sensor kemiringan dan sensor getar dapat dilihat pada Gambar 10 berikut.

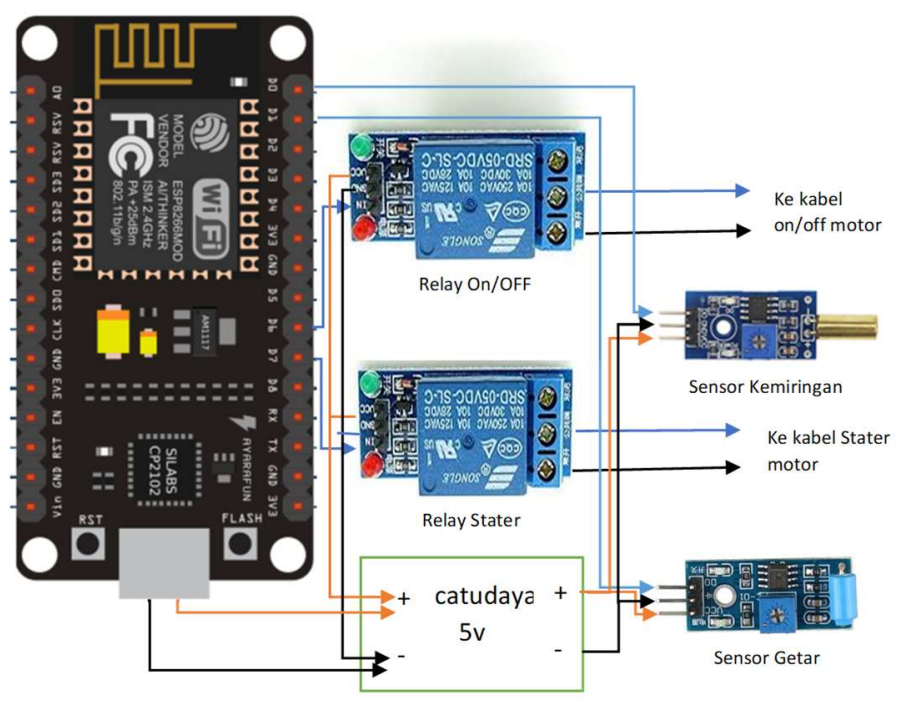

Gambar 10 Konfigurasi Hardware Sistem Pengendalian Motor Jarak Jauh 
Pemrograman sistem ini menggunakan aplikasi Arduino IDE yaitu terdiri dari beberapa proses yaitu (1) proses sinkronisasi WiFi dan aplikasi Blynk (Gambar 11), (2) proses pengaturan relay (Gambar 12), (3) proses pengaturan sensor kemiringan (Gambar 13) dan (4) proses pengaturan sensor getar (Gambar 14).

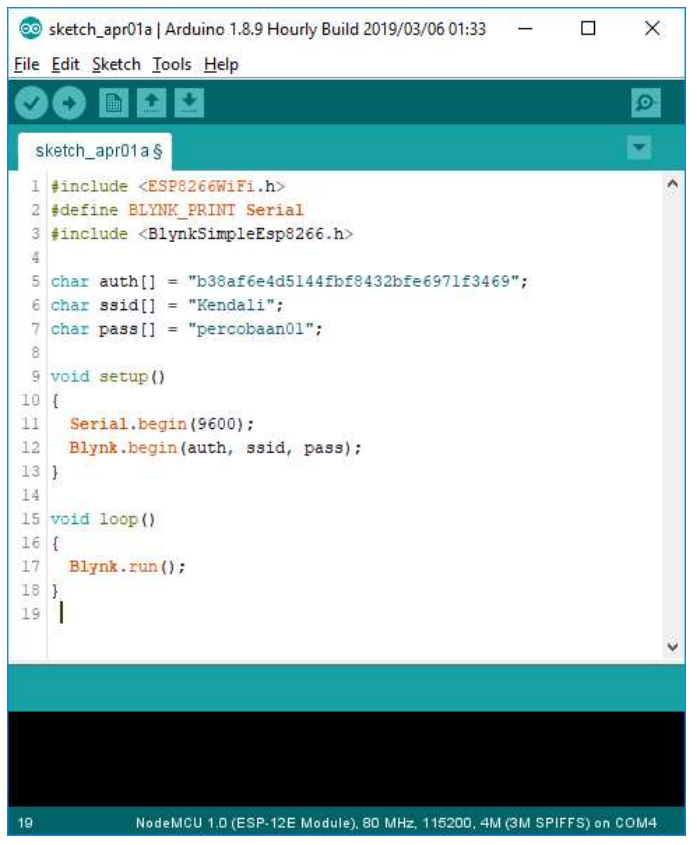

Gambar 11 Sinkronisasi Rangkaian

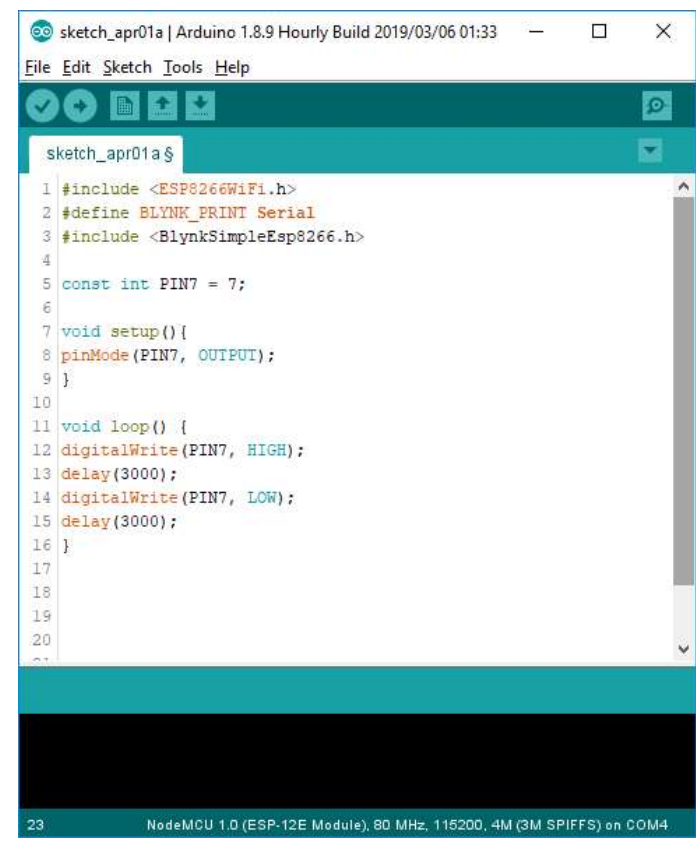

Gambar 12 Pengaturan Relay

Pada proses sinkronisasi WiFidan aplikasi Blynk (Gambar 11), penulis menetapkan SSID yang nantinya akan digunakan pada router atau hotspot yang digunakan, penetapan ini harus dilakukan dari coding. Demikian juga dengan password untuk terhubung dengan hotspot, ditetapkan dari proses ini. Selain SSID dan password, pada proses ini juga harus di ikut sertakan kode autentifikasi yang diperoleh dari aplikasi Blynk. Setelah itu baru proses sinkronisasi dapat dilakukan dan interface Blynk dapat berkomunikasi dengan rangkaian pada Gambar 10.

Pada proses pengaturan relay (Gambar12), relay yang digunakan ada 2 jenis yaitu untuk relay kunci kontak on/off dan relay starter. Relay starter dihubungkan dengan kaki D7 dan di set sebagai OUTPUT. Starter dilakukan dengan memberikan nilai $H I G H$ pada kaki D7 tersebut. Demikian juga dengan relay kunci kontak, relay ini menggunakan kaki D6 yang diatur sebagai OUTPUT. Proses starter dilakukan dengan memberikan nilai $H I G H$ pada kaki D6.

Untuk mengendalikan rangkaian dari jarak jauh, digunakan aplikasi android Blynk yang sudah dikonfigurasi agar memfungsikan relay sesuai dengan aturan flowchart pada Gambar 9 di atas. Adapun tampilan interface pengendaliannya dapat dilihat pada Gambar 15.

Sistem ini sudah di uji cobakan pada sebuah motor selama 1 bulan yaitu mulai dari tanggal 1 Maret hingga 1 April. Motor yang digunakan adalah Yamaha Mio M3 Tahun 2015 dan aplikasi android pengendali dipasang pada Smartphone Xiaomi Redmi Note 5 Pro, RAM 4 Gigabyte dan ROM 64 Gigabyte. Didapati bahwa sistem ini selalu dapat berjalan dengan baik yaitu dapat menghidupkan dan mematikan motor dari jarak jauh dan mesin dapat mati secara otomatis setelah menyala selama 10 menit atau dimatikan secara manual. 


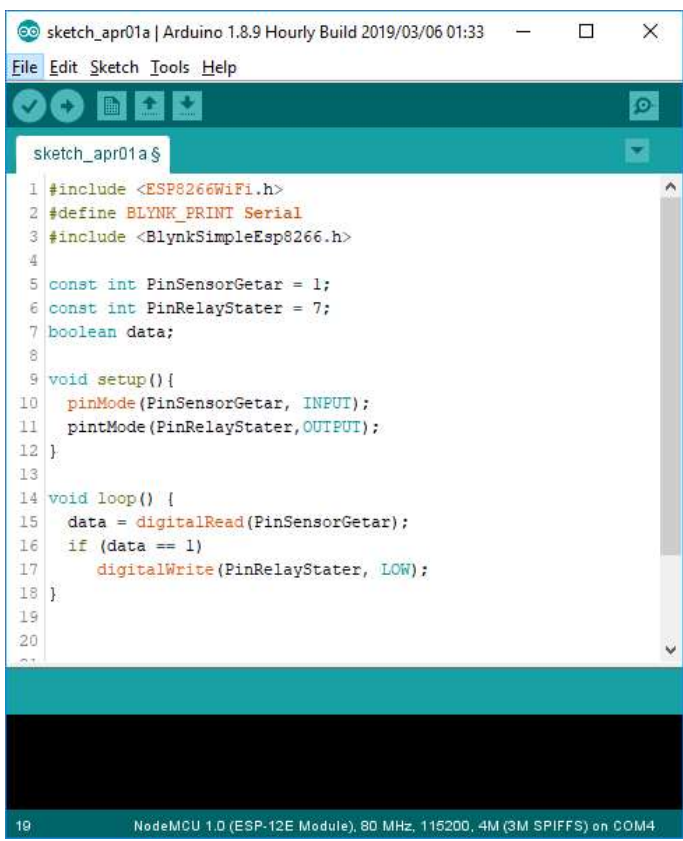

Gambar 13. Pengaturan Sensor Getar

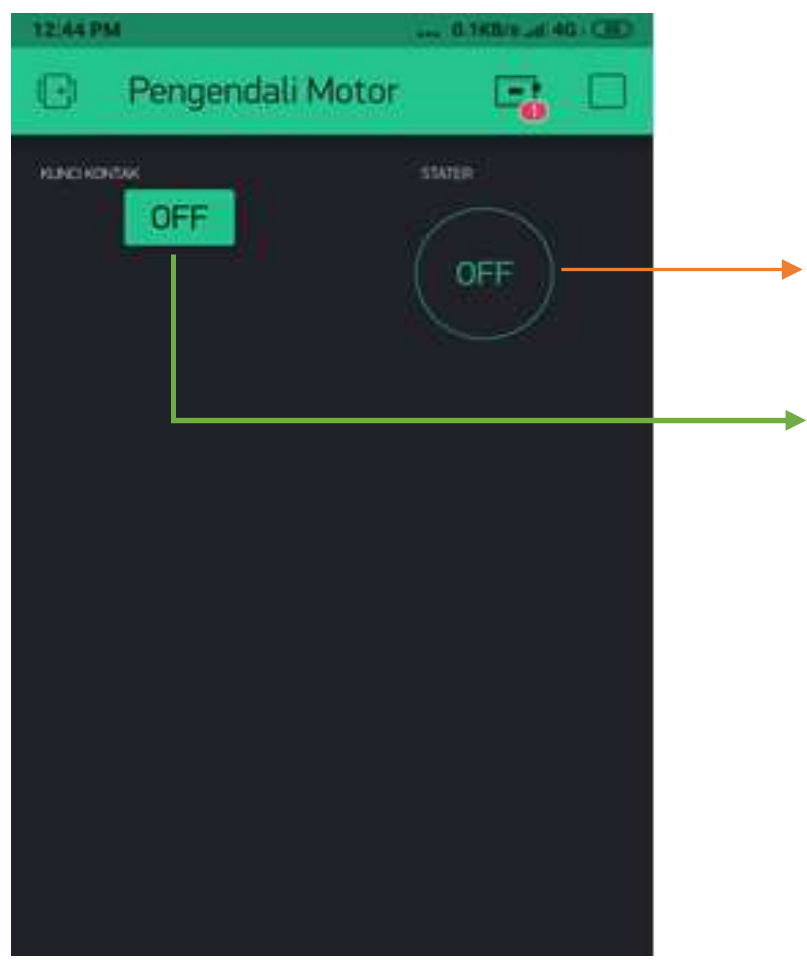

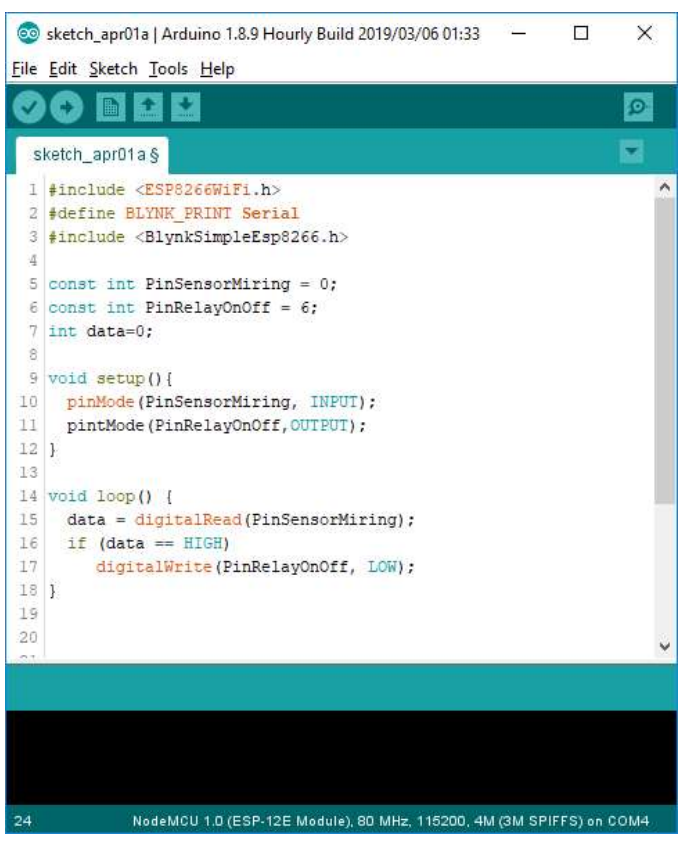

Gambar 14. Pengaturan Sensor Kemiringan

Mengendalikan Tombol

Starter

Mengendalikan kunci $\operatorname{kontak}(O N$ atau $O F F)$

Gambar 15 Tampilan Interface Pengendali Motor Jarak Jauh 


\section{Kesimpulan}

Berdasarkan penelitian yang sudah dilakukan dalam membangun sebuah sistem pengendali motor jarak jauh dapat disimpulkan :

1. Sistem pengendali motor jarak jauh dapat dibuat dengan menggunakan microcontroller NodeMCU ESP8266 yang memiliki modul WiFi. Sistem ini menggunakan 2 buah relay untuk mengendalikan kunci kontak (on/off) dan tombol starter di motor. Sistem ini dilengkapi dengan 2 buah sensor yaitu sensor getar dan sensor kemiringan.

2. Interface yang dirancang menggunakan aplikasi Blynk berbasis android dapat mengendalikan peralatan hardware yang telah dikonfigurasi sesuai dengan tujuannya. Aplikasi ini dijalankan pada smartphone android yang terhubung dengan internet, baik menggunakan WiFi maupun menggunakan kartu jaringan $3 \mathrm{G}$ maupun 4G.

3. Hasil uji coba menunjukkan bahwa aplikasi ini dapat digunakan selama NodeMCU ESP8266 mendapatkan sinyal WiFi yang memilik koneksi internet.

\section{Referensi}

[1] R. Saputra and D. Tami, "Trik Simpel Hidupkan Motor Lama Tak Dipakai, Langsung Tokcer," 29 Jun 2018. [Online]. Available: https://www.msn.com/id-id/otomotif/berita/trik-simpel-hidupkan-motorlama-tak-dipakai-langsung-tokcer/ar-AAzkyn4.

[2] J. Arifin, A. H. Saptadi and A. Silalahi, " Aplikasi Telepon Seluler Sebagai Sistem Kendali Jarak Jauh untuk Menyalakan dan Mematikan Mesin Sepeda Motor," in PROSIDING SEMINAR NASIONAL MULTI DISIPLIN ILMU UNISBANK, Semarang, 2017.

[3] M. I. Andi, Rancangan Sistm Start Engine dan Alarm pada Sepeda Motor Menggunakan Arduino Uno Berbasis Android, Surakarta, 2017.

[4] S. P. Sitrusta Sukaridhoto, Bermain dengan Internet of Things dan Big Data, Surabaya, 2016.

[5] A. Luigi, I. Antonio and M. Giacomo, "The Internet of Things : A Survey," Computer Networks, 2010.

[6] P. Singh, "NodeMCU ESP12 Dev Kit V1.0 Pin Definition," IoT Bytes, [Online]. Available: https://iotbytes.wordpress.com/nodemcu-pinout/. [Accessed April 2019].

[7] S. Samsugi, Ardiansyah2 and D. Kastutara, "INTERNET OF THINGS (IOT): Sistem Kendali Jarak Jauh," in Prosiding Seminar Nasional XII "Rekayasa Teknologi Industri dan Informasi 2017, Yogyakarta, 2017. 